\title{
Accelerator of innovations for pre-incubation stage of project lifecycle
}

\author{
Inga Skvortsova ${ }^{1}$ and Yury Nurulin ${ }^{1, *}$, \\ ${ }^{1}$ Peter the Great Saint-Petersburg Polytechnic University, 29, Polytechnicheskaya, 195251, Saint- \\ Petersburg, Russia
}

\begin{abstract}
The article is aimed at developing cogent proposals to shorten the implementation of pre-incubation stage of the innovation lifecycle. To achieve the goal, we proposed a framework to formalized description of innovative systems that allowed us to identify structure and set of elements of the system that are invariant with respect to its levels. The analysis of the most popular innovation process models allowed us to single out the feedback as a key structural element of the system, which to a large extent determines the dynamics of the innovation process. It is shown that the absence of specialized infrastructural elements of innovation systems that could provide cross-cutting feedback at the pre-incubation stage is a deterrent to accelerate innovation.
\end{abstract}

\section{Introduction}

To make the sustainable impact on development of the innovation system, the intermediaries shall be equipped with a set of new tools that make their support for innovation processes more effective. These newly created tools should also allow the intermediary organisations to meet the needs of SMEs and start-ups in the field addressed. Furthermore, relevant stakeholders shall start cooperating when supporting the commercialisation of products and testing innovative products and services. The long term challenge identified as necessity to accelerate the innovation process is to help innovation system to become a frontrunner in sustainable innovation and entrepreneurship through improvement of the business landscape.

\subsection{Generations of the innovation process model}

Technological change is a complex process that has not been fully studied yet. This complexity is partly associated with a diverse set of phenomena, which are referred to as the term "innovations". Very different phenomena have made generalization of innovation process difficult. For a long time thinking about technological change and innovation has been guided by linear models. In the 1950s and 1960s the most widespread models were the technology-push models and then the need-pull models. It was assumed that in the first case, the development, production and marketing of new technologies would follow a clearly

* Corresponding author: yury.nurulin@gmail.com 
defined time sequence that began with fundamental and applied research, including the stage of product development, and then led to production and possibly commercialization. In the second model, the source of ideas and the initiator for the linear sequential R\&D process was solvent demand and market requirements.

In the $1970 \mathrm{~s}$, the third generation of the innovation process model was represented by a combined model. This model showed that both technological and pulling models did not contain an adequate description of the innovation processes. At the same time, innovations appear on the market as a result of a special process, consisting of separate but interacting and interdependent stages, covered by feedback and with various links to research communities. Hence, the focus was on interactions between phases and actors that were combined $[1,2]$.

The beginning of the 1980s was a period when companies were conscious of the strategic importance of developing and using new technologies and organizational innovations. The successes of Japanese firms that created a system of high-quality manufacturing with low production costs and short design cycle have become a kind of impetus for development of a new model of innovation process based on the integration of external and internal participants in product development processes.

In the late 1990s, the fifth generation of the innovation process model was disseminated. The information and communication technologies (ICT) play a key role in this model. Many researchers note that ICT have the ability to accelerate all the components of the innovation process [3-5].

The desire to increase the effectiveness of innovation process underlies the open innovation paradigm, which has become widespread at the same time [6]. Open innovations are designed to change the initial stages of innovation process, when the idea of an innovative project is formed and the necessary set of technological solutions is determined. The essence of the proposed changes consists in shifting the focus to external research and knowledge of outside experts in the organizing of R\&D necessary for the innovation process. As a result, the number of successfully implemented innovation projects is significantly increased and the period of their implementation is shortened.

\subsection{Feedback in the innovation lifecycle}

The above models that have been used for formulation of national R\&D policies in the past, have come criticized in recent years for several reasons, not the least of which is the lack of feedback at several stages of the project life-cycle. Intensifying competition and shorter product life cycles require a closer integration of $R \& D$ with the other phases of the innovation process. This criticism has led to a broader view of the process of innovation as an interactive process with a multilevel feedback (fig.1).

Currently, the evolving theory of innovation emphasizes the central role of the feedback effects between the phases of the innovation process in the downstream and upstream flows, and testing is a natural tool for obtaining this feedback [7]. As markets become customer-focused, customers focus on the scale of product success and technological innovation. This creates new challengers for innovators, as they need to adapt innovations to the dynamically changing needs of customers and to speed up commercialization process. The creation of innovation in this dynamic environment cannot rely anymore on standardized linear processes, but must be based on flexible processes that allow an acceleration of innovation as speed becomes crucial. 


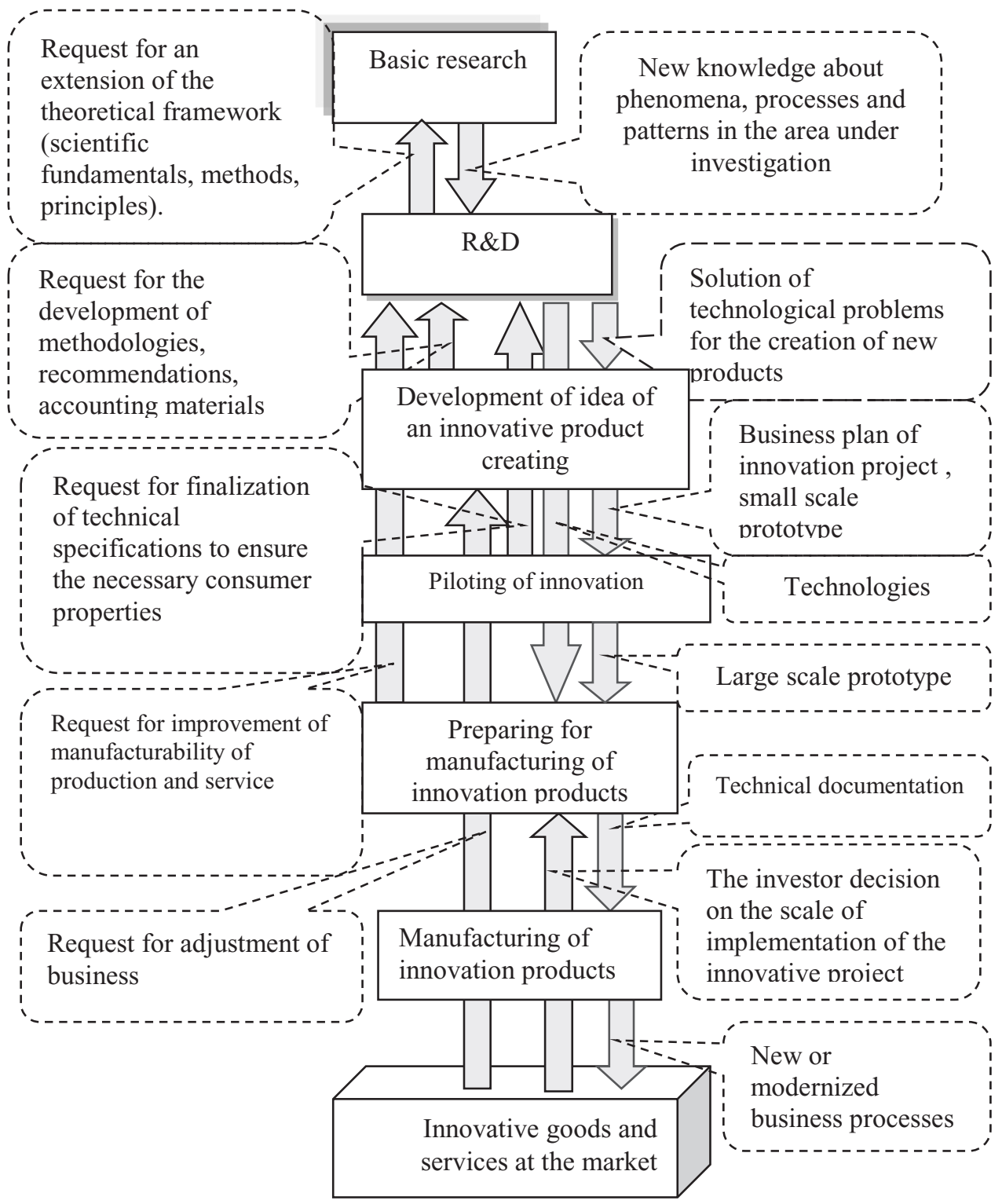

Fig. 1. Feedback in innovation process.

\section{The problem definition}

The above last generations of the innovation processes models consider the acceleration and reduction of the terms of innovation cycle as one of the key tasks. At the same time these models describe the static of innovation processes while a process is dynamic system. Implicitly the process dynamics in these models is reflected in the form of logical interaction chains of model elements, including feedback. There are no selected elements which provide feedback for acceleration of separate stages of innovation lifecycle at these models. The need for such elements is determined by the fact that the structure and content of tasks that are being addressed at different stages of the life cycle are significantly different. Hence, the 
methods and means of acceleration must be different. In other words, in addition to common acceleration tools, such as ICT, for each stage of the life cycle of innovation, their own tools must be used. The subject of this study is the accelerator for the initial stages of the innovation life cycle (Fig. 2).

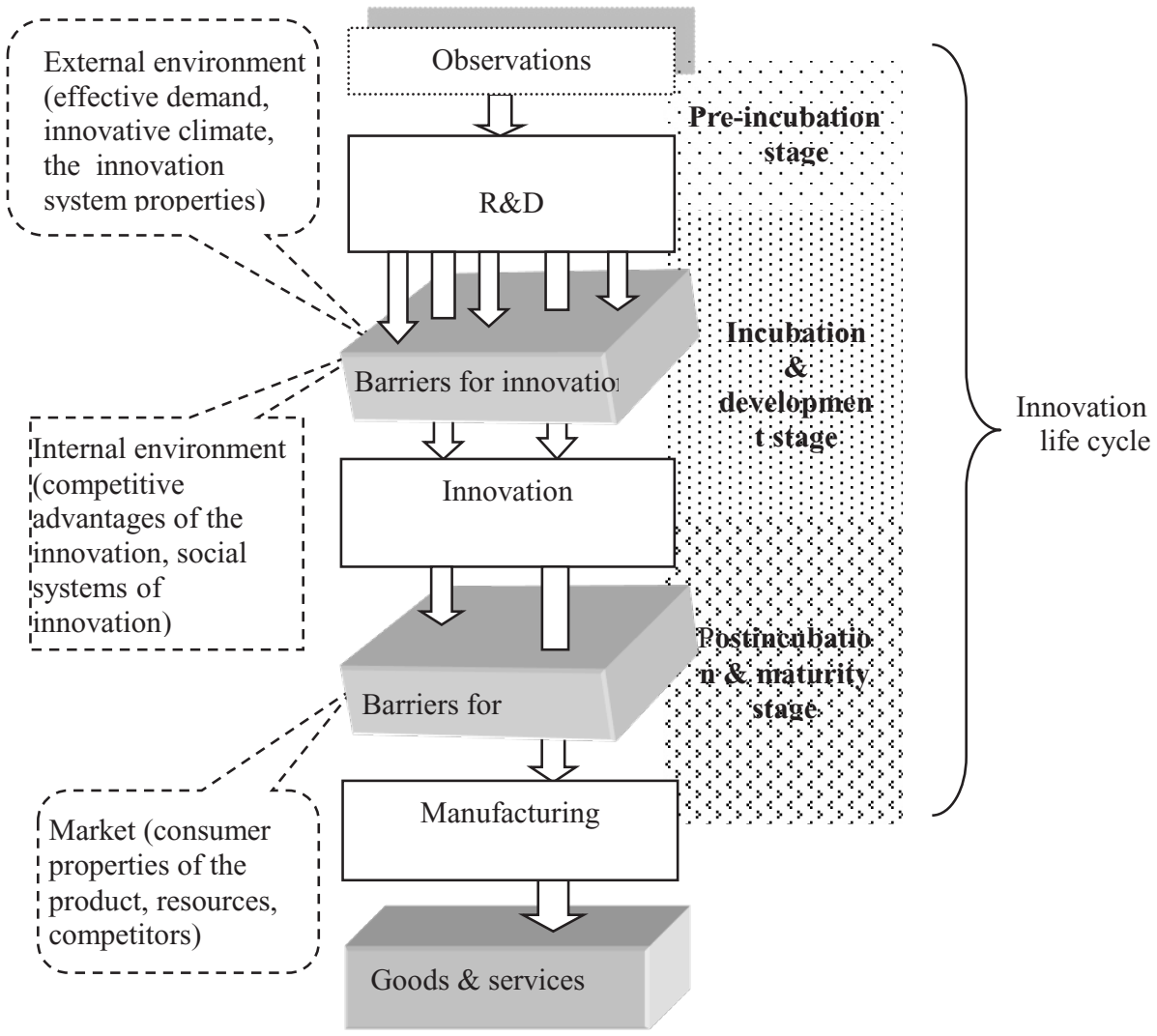

Fig. 2. Innovation lifecycle and its stages.

\section{The acceleration in the context of innovation systems}

Both the high-tech innovation industries and the traditional industry striving for innovation often lack a clear understanding of existing market needs due to the high dynamics of changes in the knowledge-based economy. Lack of knowledge about specific demand is replaced by a general idea of the development directions of future technologies and the demand for their applications. This is reflected in directions of development of innovation systems in general, and its elements and the tools used for development of innovations in particular.

The innovation system is an interconnected set of elements, corresponding to the known characteristics of the system:

$$
\mathrm{Si}=<\mathrm{Ai} \text { Ei NiPi Ui> }
$$

where $\left\{A_{i}\right\}$ is the set of innovation actors; $\left\{E_{i}\right\}$ is the set of elements of innovation infrastructure elements; $\left\{N_{i}\right\}$ is the set of normative and legal documents which create a legal framework for innovation activity; $\left\{P_{i}\right\}$ is the set of innovation priorities, $\left\{U_{i}\right\}$ is the set of financial and other sources for support of innovation.

Traditionally, researchers identify the national, regional and corporate levels of 
innovation systems. The concept of national innovation systems (NIS) was proposed by Freeman in 1987, and was further developed by Porter in 1990, Lundwal in 1992, Nelson et al. in 1993, and by other studies [8-10]. The main idea of the NIS concept is that the innovation process in the state should be coordinated and rely on both private and public institutions. The concept of regional innovation system (RIS) was formulated by Braczyk et all in 1996 [11]. Later it was developed in a number of works [12-14]. The key elements of RIS are innovative actors - innovative companies interacting with the external environment, which is formed by competitors, suppliers, customers, authorities and other external organizations on the basis of regional policy, territorial, social and cultural and other features of the business environment of the region. An important role in RIS is assigned to universities and other scientific organizations that form knowledge, which are the basis for the innovation process, as well as to the network structures that ensure the dissemination of innovations. Since the early 2000s, there has been a growing interest in the subregional dimensions of innovation systems, partly because of a growing dissatisfaction with their relevance at the national and regional levels [15]. In recent years there has been a growing interest in the study of corporate innovation systems (CIS) [16-18]. Being active actors of NIS and RIS, large corporations, universities and other participants themselves represent a rather complex system, which draws all elements according to (1). Summarizing the above studies, and also using the results of monitoring of innovation systems in Russia and abroad, we came to conclusion that description of the innovation system in the form of (1) allows us to distinguish a supranational level - international innovation systems (Table $1)$.

Table 1. Types and composition of innovation systems.

\begin{tabular}{|c|c|c|c|c|}
\hline & $\begin{array}{c}\text { International } \\
\text { Innovation Systems } \\
\text { IIS }\end{array}$ & $\begin{array}{c}\text { National Innovation } \\
\text { Systems } \\
\text { NIS }\end{array}$ & $\begin{array}{c}\text { Regional Innovation } \\
\text { Systems } \\
\text { RIS }\end{array}$ & $\begin{array}{c}\text { Corporate } \\
\text { Innovation } \\
\text { Systems } \\
\text { CIS }\end{array}$ \\
\hline $\begin{array}{c}\text { Elements } \\
\text { of the set } \\
\qquad\left\{\boldsymbol{A}_{i}\right\}\end{array}$ & $\begin{array}{l}\text { Transnational } \\
\text { corporations } \\
\text { realizing innovative } \\
\text { projects. National } \\
\text { companies working } \\
\text { with external } \\
\text { markets for } \\
\text { innovation. } \\
\text { International } \\
\text { innovative } \\
\text { networks. } \\
\text { Innovative } \\
\text { communities }\end{array}$ & $\begin{array}{l}\text { National institutes of } \\
\text { innovative } \\
\text { development. } \\
\text { National companies } \\
\text { supplying innovative } \\
\text { products and services } \\
\text { to domestic market. } \\
\text { National innovation } \\
\text { networks }\end{array}$ & $\begin{array}{l}\text { Stakeholders which } \\
\text { determine the } \\
\text { strategy and tactics } \\
\text { of innovative } \\
\text { development of the } \\
\text { region. Companies } \\
\text { of the region using } \\
\text { its key resources for } \\
\text { innovation. } \\
\text { Regional clusters }\end{array}$ & $\begin{array}{l}\text { Specialized } \\
\text { innovative } \\
\text { divisions of } \\
\text { the company. } \\
\text { Management } \\
\text { bodies that } \\
\text { determine the } \\
\text { innovative } \\
\text { strategy and } \\
\text { tactics of the } \\
\text { company. } \\
\text { Innovators }\end{array}$ \\
\hline $\begin{array}{c}\text { Elements } \\
\text { of the set } \\
\left.\qquad \boldsymbol{E}_{i}\right\}\end{array}$ & $\begin{array}{l}\text { International } \\
\text { organizations that } \\
\text { provide financial } \\
\text { support to legal } \\
\text { entities and } \\
\text { innovators. } \\
\text { Specialized } \\
\text { information systems } \\
\text { focused on } \\
\text { innovation. }\end{array}$ & $\begin{array}{l}\text { Specialized national } \\
\text { organizations } \\
\text { providing financial, } \\
\text { consulting, technical } \\
\text { and information } \\
\text { support to legal } \\
\text { entities and } \\
\text { individuals }\end{array}$ & $\begin{array}{l}\text { Innovation } \\
\text { intermediaries and } \\
\text { support } \\
\text { organizations in the } \\
\text { region (business } \\
\text { incubators, } \\
\text { technoparks, } \\
\text { innovation centers, } \\
\text { technology transfer } \\
\text { centers etc. }\end{array}$ & $\begin{array}{l}\text { Specialized } \\
\text { divisions of } \\
\text { the company, } \\
\text { whose } \\
\text { business } \\
\text { models are } \\
\text { focused on } \\
\text { services to } \\
\text { innovative } \\
\text { divisions of } \\
\text { the company }\end{array}$ \\
\hline
\end{tabular}




\begin{tabular}{|c|c|c|c|c|}
\hline $\begin{array}{c}\text { Elements } \\
\text { of the set } \\
\left\{N_{i}\right\}\end{array}$ & $\begin{array}{l}\text { International } \\
\text { agreements for joint } \\
\text { development tools } \\
\text { or for restrictions } \\
\text { for certain activities } \\
\text { or products. }\end{array}$ & $\begin{array}{l}\text { National laws and } \\
\text { other legal acts } \\
\text { regulating taxation, } \\
\text { measures of } \\
\text { restrictions and } \\
\text { stimulating of } \\
\text { innovation }\end{array}$ & $\begin{array}{l}\text { Regional laws and } \\
\text { other normative acts } \\
\text { on regulation of } \\
\text { innovation } \\
\text { activities, including } \\
\text { the regional budget }\end{array}$ & $\begin{array}{l}\text { The } \\
\text { company's } \\
\text { strategy, } \\
\text { expressed in } \\
\text { the documents } \\
\text { approved by } \\
\text { the } \\
\text { management }\end{array}$ \\
\hline $\begin{array}{c}\text { Elements } \\
\text { of the set } \\
\left\{\boldsymbol{U}_{i}\right\}\end{array}$ & $\begin{array}{l}\text { International } \\
\text { innovative } \\
\text { programs. } \\
\text { Educational } \\
\text { programs to support } \\
\text { mobility for the } \\
\text { development of } \\
\text { innovation. } \\
\text { International } \\
\text { Innovation Forums } \\
\text { and Exhibitions }\end{array}$ & $\begin{array}{l}\text { National innovative } \\
\text { programs that } \\
\text { provide subsidies and } \\
\text { grants, as well as } \\
\text { ordering innovative } \\
\text { products. } \\
\text { Educational } \\
\text { programs for } \\
\text { innovation } \\
\text { management }\end{array}$ & $\begin{array}{l}\text { Regional programs } \\
\text { to support } \\
\text { innovative } \\
\text { development, grants } \\
\text { to legal entities and } \\
\text { individuals of the } \\
\text { region. Innovation } \\
\text { awards }\end{array}$ & $\begin{array}{l}\text { Internal } \\
\text { regulations of } \\
\text { the company, } \\
\text { which } \\
\text { stimulate staff } \\
\text { and provide } \\
\text { financial } \\
\text { resources and } \\
\text { support for } \\
\text { innovators }\end{array}$ \\
\hline $\begin{array}{l}\text { Elements } \\
\text { of the set } \\
\left\{\mathrm{P}_{i}\right.\end{array}$ & $\begin{array}{l}\text { Formed and } \\
\text { accepted by the } \\
\text { international } \\
\text { community } \\
\text { directions of } \\
\text { scientific and } \\
\text { technical } \\
\text { development of } \\
\text { society, science and } \\
\text { technology }\end{array}$ & $\begin{array}{l}\text { National priority } \\
\text { areas for the } \\
\text { development of } \\
\text { science and } \\
\text { technology, critical } \\
\text { technologies that } \\
\text { determine the } \\
\text { country's global } \\
\text { competitiveness }\end{array}$ & $\begin{array}{l}\text { Regional priorities } \\
\text { of innovative } \\
\text { development, taking } \\
\text { into account the } \\
\text { geographically } \\
\text { determined role of } \\
\text { the region in the } \\
\text { division of labor } \\
\text { and the world } \\
\text { economic system }\end{array}$ & $\begin{array}{l}\text { Programs of } \\
\text { innovative } \\
\text { development, } \\
\text { areas of the } \\
\text { greatest } \\
\text { competencies } \\
\text { of the } \\
\text { enterprise } \\
\text { employees }\end{array}$ \\
\hline
\end{tabular}

\section{Logic of study}

The proposed framework for the innovative systems definition makes it possible to identify those elements of the system that have the greatest effect on the quality of feedback in the system. These elements belong to sets $\left\{E_{i}\right\}$ and $\left\{U_{i}\right\}$. Elements of the infrastructure provide an internal (physical) opportunity for feedback, and support mechanisms provide external conditions for effective work (financing, consulting support, social incentives).

Within the framework of the task the next level of the monitoring of innovation systems was concentrated at selected sets. During the monitoring, elements were identified, the main function of which is formation of the necessary feedback in different stages of innovation lifecycle. In total, more than 60 elements of innovation infrastructure and more than 20 events and instruments for supports of innovators were studied. In the course of monitoring it was found that quite often the innovation infrastructure elements, as well as innovation support activities, have names that reflect their marketing potential, rather than functional characteristics, making it difficult to analyze their effectiveness. To avoid this difficulty, the innovation process was presented as a set of stages of innovation lifecycle (SIL) reflected technology development and level of testing (Table 2).

Table 2. Testing in the innovation process.

\begin{tabular}{|l|l|l|l|}
\hline & $\begin{array}{l}\text { Content of the } \\
\text { innovation activity }\end{array}$ & Level of testing & $\begin{array}{l}\text { Elements of innovation } \\
\text { infrastructure }\end{array}$ \\
\hline
\end{tabular}




\begin{tabular}{|c|c|c|c|}
\hline SIL 0 & Unproven concept & $\begin{array}{l}\text { No testing have been } \\
\text { performed }\end{array}$ & Innovation co-workings \\
\hline SIL 1 & Basic research & $\begin{array}{l}\text { Principles postulated and } \\
\text { observed but no experimental } \\
\text { proof available }\end{array}$ & $\begin{array}{l}\text { Research laboratories at } \\
\text { universities and research } \\
\text { institutes }\end{array}$ \\
\hline SIL 2 & $\begin{array}{l}\text { Technology } \\
\text { frameworks } \\
\text { formulation }\end{array}$ & $\begin{array}{l}\text { Concept and application have } \\
\text { been formulated }\end{array}$ & $\begin{array}{l}\text { Centers of technology } \\
\text { transfer }\end{array}$ \\
\hline SIL 3 & Applied research & $\begin{array}{l}\text { First laboratory tests of } \\
\text { technological parameters } \\
\text { completed. }\end{array}$ & $\begin{array}{l}\text { Innovation-technology } \\
\text { centers, Centers for } \\
\text { collective use of high-tech } \\
\text { equipment }\end{array}$ \\
\hline SIL 4 & Prototyping & $\begin{array}{l}\text { Small scale prototype to test } \\
\text { technical parameters }\end{array}$ & $\begin{array}{l}\text { FabLab, Centers of fast } \\
\text { prototyping }\end{array}$ \\
\hline SIL 5 & $\begin{array}{l}\text { Consumer properties } \\
\text { demonstration }\end{array}$ & $\begin{array}{l}\text { Large scale prototype to test } \\
\text { the system in intended } \\
\text { environment }\end{array}$ & \\
\hline SIL 6 & $\begin{array}{l}\text { First of a kind } \\
\text { commercial system }\end{array}$ & Manufacturing issues solved & Technoparks \\
\hline SIL 7 & $\begin{array}{l}\text { Full commercial } \\
\text { application }\end{array}$ & $\begin{array}{l}\text { Technology available for } \\
\text { consumers }\end{array}$ & $\begin{array}{l}\text { Technopolices and Special } \\
\text { economic zones with } \\
\text { privileges for innovative } \\
\text { companies }\end{array}$ \\
\hline
\end{tabular}

Two different levels of testing were identified: testing in a single stage (business plan evaluation, experiment etc.) and cross-cutting testing. The last one is more important since it's absence could create more essential delays for innovation development.

The study shows that there is no specialized elements of innovation infrastructure oriented to large scale prototyping to test the system in intended environment. The main task of this SIL is finalization of technical specifications to ensure the necessary consumer properties (see Fig. 1). The similar result was obtained from analysis of supporting mechanisms for this type of the feedback.

\section{Conclusion}

The luck of infrastructure elements of innovation systems which are focused on testing of developed innovation products and services could become a challenge for acceleration of innovations at pre-incubation stage. Some examples of attempts to solve this problem (Living Labs in Europe, Innovation Sandboxes in Russia) show that innovation stakeholders become aware of the importance of this problem. The system approach to solving this problem requires coordinated changes in all selected elements of innovation system including behavior of innovation actors. Thus a road map for acceleration of innovation should contain coordinated measures on creation of specialized infrastructure elements for testing innovative products and services and on corresponding training and coaching of innovators at preincubation stages to prove importance and significance of these elements for accelerating the innovations.

\section{References}

1. R. Rothwell, W. Zegveld, Reindustrialization and technology (Longman, 1985)

2. S.J. Kline, N. Rosenberg, An overview of innovation. In: R.,Landau, N.Rosenberg (eds.) The positive sum strategy. (NAP, 1986) 
3. V.V. Glukhov, I.V. Ilin, O.Y. Iliashenko, Improving the Efficiency of Architectural Solutions Based on Cloud Services Integration (Springer, 2016)

4. A.D. Andersen, P.D. Andersen, Innovation system foresight, Technological Forecasting \& Social Change 88, 276-286 (2014)

5. V.V. Glukhov, I.V. Ilin, A.B. Anisiforov, Problems of data protection in industrial corporations enterprise architecture (ACM, 2015)

6. H. Chesbrough, HBS Press, 272 (2003)

7. M. Fischer, Innovation, knowledge creation and systems of innovation (ARS, 2001)

8. C. Freeman, The National System of Innovation in historic perspective, CJE, 5-24 (1995)

9. B.A. Lundvall, Industry and Innovation, 95-119 (2007)

10. R.R. Nelson (ed.), National innovation systems. A comparative analysis, Oxford University Press, (1993)

11. H.J. Braczyk, P. Cooke, M. Heidenreich, UCL Press, 139-168 (1996)

12. F. Alkemade, C. Kleinschmidt, M. Hekkert, Analysing emerging innovation systems: a functions approach to foresight, Int. J. Foresight Innov. (2007)

13. B.T. Asheim, M. Gertler, The geography of innovation: regional innovation systems (The Oxford University Press, 2005)

14. P. Cooke, M. Heidenreich, H. Braczyk, Regional Innovation Systems (Routledge, 2004)

15. C. Carrincazeaux, F. Gaschet, Regional Innovation Systems and Economic Performance: Between Regions and Nations, European Planning Studies, 262-291 (2015)

16. Q.R. Xu, Z.Y. Wu, S.P. Zhang, S.Y Liu, Total innovation management paradigm for firm innovation system, ICMIT, 359-364 (2014)

17. L.I. Fedulova, Actual Problems of Economics 160(1), 195-205 (2014)

18. A.G. Guseynov, T.A. Fadhil, Life Science Journal 11, 99-103 (2014) 